\title{
UPAYA MENINGKATKAN AKTIVITAS BELAJAR SISWA DENGAN MODEL PROJECT BASED LEARNING
}

\author{
Rini Rosita Tarigan *) dan Naeklan Simbolon**)
}

\author{
*) Mahasiswa Jurusan PPSD \\ **) Dosen juruan PPSD Prodi PGSD FIP UNIMED
}

naeklan.simbolon@yahoo.com

\begin{abstract}
ABSTRAK
Masalah dalam penelitian adalah rendahnya aktivitas belajar siswa pada mata pelajaran IPA kelas IV. Penelitian ini bertujuan untuk mengetahui peningkatan aktivitas belajar siswa pada mata pelajaran IPA dengan menggunakan model project based learning di kelas IV. Penelitian ini termasuk penelitian tindakan kelas. Penelitian dilaksanakan di SDN 101869 Desa Sena Kec. Batang Kuis Kab. Deli Serdang T.A 2014/2015. Penelitian dilaksanakan pada bulan Maret sampai bulan Mei 2015. Subjek penelitian adalah siswa kelas IV yang terdiri dari 26 orang dan objeknya adalah peningkatan aktivitas belajar siswa dengan menggunakan model project based learning. Penelitian dilakukan sebanyak dua siklus dengan masing-masing siklus terdiri dari dua pertemuan. Setiap silkus dilakukan perencanaan, pelaksanaan, pengamatan, dan refleksi. Hasil refleksi silkus I dijadikan acuan untuk pelaksanaan siklus II. Teknik pengumpulan data yang digunakan adalah observsi aktivitas belajar siswa. Berdasarkan siklus I diperoleh bahwa dari 26 siswa, 18 orang siswa aktif $(69,23 \%)$ dan 8 orang siswa tidak aktif $(30,76 \%)$ dengan nilai nilai rata-rata kelas 67,82. Karena hasil belum sesuai dengan yang diharapkan maka dilakukan perbaikan pada siklus II. Dari 26 siswa pada siklus II, 25 orang siswa aktif $(96,15 \%)$ dan 1 orang siswa tidak aktif $(3,85 \%)$ dengan nilai rata-rata kelas adalah 84,42 . Berdasarkan hasil analisis data dapat disimpulkan bahwa dengan menggunakan model project based learning dapat meningkatkan aktitivitas belajar siswa.
\end{abstract}

Kata Kunci: aktivitas belajar, model project based learning

\begin{abstract}
Problems that are reviewed through this study is the low activity of students in the fourth grade science subjects. This study aims to determine the increase in students' learning activities in science subjects by using the model of project-based learning in class IV. This study includes classroom action research. SDN 101869 Research conducted in the village of Sena district Batang Kuis Kab. Deli Serdang T.A 2014/2015. The research was conducted from March to May 2015. The subjects were students of class IV consisting of 26 people, and its object is to increase
\end{abstract}


students' learning activities using project based learning models. The study was conducted by two cycles with each cycle consisting of two meetings. In the first cycle is done the planning, implementation, observation, and reflection. Results of the first cycle of reflection will be used as a reference for the implementation of the second cycle. Data collection techniques used were observational learning activities of students. Based on the analysis of data obtained the following results: of the 26 students in the first cycle class average value is 67.82 with 18 active students (69.23\%) and 8 students are not active (30.76\%). Because the result is not as expected then carried out repairs on the second cycle. Of the 26 students in the second cycle class average value is 84.42 with 25 active students (96.15\%) and 1 inactive students (3.85\%). From the data analysis it can be concluded that by using the model of project-based learning can improve student learning activities.

Keywords: learning activities, learning model, project-based learning

\section{PENDAHULUAN}

Pendidikan merupakan faktor penting bagi kelangsungan kehidupan manusia dan faktor pendukung yang memegang peranan penting di seluruh sektor kehidupan, sebab kualitas kehidupan seseorang sangat erat dengan tingkat pendidikan. Pendidikan merupakan pintu utama bagi peserta didik untuk membangun pengetahuan sebagai usaha menciptakan manusia berkualitas yang memiliki kedewasaan, baik kedewasaan intelektual, sosial maupun kedewasaan moral sekaligus memiliki daya saing dalam menghadapi kemajuan di bidang ilmu pengetahuan dan teknologi yang semakin berkembang dari waktu ke waktu. Untuk menghadapi perkembangan ilmu pengetahuan dan teknologi maka peserta didik sangat perlu menguasai mata pelajaran Ilmu pengetahuan alam.

Ilmu Pengatahuan Alam (IPA) merupakan salah satu mata pelajaran yang penting bagi peserta didik, karena IPA diperlukan dalam kehidupan sehari-hari untuk memenuhi kebutuhan manusia melalui pemecahan masalah.
Melalui pelajaran IPA diharapkan peserta didik dapat mempelajari tentang dirinya dan alam sekitar serta mampu menerapkannya di dalam kehidupan sehari-hari. Pelajaran IPA sangat erat kaitannya dengan cara mencari tahu tentang alam semesta secara sistematis, sehingga sains bukan hanya penguasaan kumpulan pengetahuan berupa fakta-fakta, konsep-konsep atau prinsip saja, tetapi juga merupakan proses penemuan bagaimana pengetahuan itu diperoleh.

IPA di Sekolah Dasar mempunyai peranan yang sangat penting dalam membentuk dan menumbuhkan kemampuan berpikir, bekerja dan bersikap ilmiah pada siswa untuk diaplikasikan dalam kehidupan sehari-hari. Pembelajaran di kelas sangat membutuhkan keaktifan siswa, oleh karena itu hal paling mendasar yang dituntut dalam proses pembelajaran yang dialami siswa adalah aktivitas siswa. Dengan adanya keterlibatan siswa dalam berbagai aktivitas siswa pada saat proses belajar mengajar maka akan tercipta proses belajar mengajar yang baik. Oleh 
karena itu seorang guru diharapkan dapat merencanakan dan melaksanakan pembelajaran yang sesuai dengan kurikulum dan memacu aktivitas belajar siswa dalam pembelajaran. Sehingga tujuan pembelajaran dapat tercapai dengan optimal.

Berdasarkan observasi yang diperoleh selama peneliti di SD Negeri 101869 Desa Sena, keadaan dan kondisi yang ditemukan menunjukkan bahwa selama proses pembelajaran di kelas masih kurang dalam memicu aktivitas belajar siswa. Kegiatan pembelajaran yang seharusnya menarik minat siswa untuk membangun pengetahuannya dengan belajar yang menyenangkan dan memacu aktivitas belajar siswa, justru tidak adadengan kata lain aktivitas belajar siswa pada pelajaran IPA masih rendah. Melihat kenyataan di sekolah, maka perlu diterapkan model pembelajaran yang dapat meningkatkan aktivitas belajar siswa khususnya pada pelajaran IPA. Salah satu model yang dapat meningkatkan aktivitas belajar siswa adalah model project based learning. Model project based learning (PjBL) merupakan salah satu model yang sangat melibatkan aktivitas dan kreativitas siswa dalam belajar. Pada model project based learning siswa dituntut mampu untuk merancang, membuat, dan menampilkan produk untuk mengatasi permasalahan dunia nyata.

Hakekatnya belajar merupakan proses perubahan di dalam kepribadian yang berupa kecakapan, sikap, kebiasaan, dan kepandaian. Perubahan yang dimaksudkan adalah perubahan tingkah laku dari hasil latihan dan pengalaman. Menurut Robert Gagne (dalam Istarani 2012:4) "belajar adalah suatu proses yang kompleks dan hasil belajar berupa kapabilitas, timbulnya kapabilitas disebabkan stimulasi yang berasal dari lingkungan dan proses kognitif yang dilakukan oleh pelajar". Hal ini didukung oleh Trianto (2011:17) mengartikan "belajar sebagai proses perubahan perilaku tetap dari belum tahu menjadi tahu, dari tidak paham menjadi paham, dari kurang terampil menjadi lebih terampil, dan dari kebiasaan lama menjadi kebiasaan baru, serta bermanfaat bagi lingkungan maupun individu itu sendiri”.

Aktivitas merupakan kegiatan. Jadi setiap kegiatan yang kita laksanakan merupakan aktivitas. Sama halnya dalam proses belajar- mengajar aktivitas merupakan hal yang sangat penting. Seperti yang dikemukakan oleh Sardiman (2011:95) "tidak ada belajar kalau tidak ada aktivitas". Hal ini menunjukkan bahwa dalam setiap proses belajar-mengajar pasti ada aktivitas. Menurut Sardiman aktivitas belajar itu adalah aktivitas yang bersifat fisik maupun mental. Dalam kegiatan belajar ke dua aktivitas itu harus selalu berkaitan". Seperti yang dikemukakan oleh Wena (2014:52) bahwa: "idealnya aktivitas pembelajaran tidak hanya difokuskan pada upaya mendapatkan pengetahuan sebanyak-banyaknya, melainkan juga bagaimana menggunakan segenap pengetahuan yang didapat untuk menghadapi situasi baru atau memecahkan masalah-masalah khusus 
yang ada kaitannya dengan bidang studi yang dipelajari”.

Sesuai dengan pengertian aktivitas belajar yang disebutkan sebelumnya maka aktivitas belajar merupakan suatu hal yang penting dalam proses pembelajaran dan juga dalam menciptakan siswa aktif. Aktivitas tidak terjadi begitu saja. Ada faktor yang membangkitkan atau justru menurunkan aktivitas seseorang. Faktor tersebut bisa datang dari diri sendiri (faktor intern) maupun orang lain (faktor ekstern). Menurut Daryanto (2010:36) faktor intern terdiri dari 3 faktor yaitu : “a) Faktor jasmaniah yang meliputi faktor kesehatan dan cacat tubuh. b) Faktor psikologis yang meliputi intelegensi, perhatian, minat, bakat, motif, kematangan, dan kesiapan. c) Faktor kelelahan". Menurut Daryanto (2010:44) faktor sekolah yang mempengaruhi aktivitas belajar yaitu : "metode mengajar, kurikulum, relasi guru dan siswa, relasi siswa dengan siswa, disiplin sekolah, pelajaran, waktu sekolah, ...".

Mc Keachie (dalam Yamin, 2013:77) mengemukakan 7 aspek terjadinya keaktifan siswa yaitu : “1) partisipasi siswa dalam menetapkan tujuan kegiatan pembelajaran. 2) tekanan pada aspek apektif dalam belajar. 3) partisipasi siswa dalam kegiatan pembelajaran, terutama yang berbentuk interaksi antar siswa. 4) kekompakan kelas sebagai kelompok belajar. 5) kebebasan belajar yang diberikan kepada siswa, dan kesempatan untuk berbuat serta mengambil keputusan penting dalam proses pembelajaran. 6) pemberian waktu untuk menanggulangi masalah pribadi siswa, baik berhubungan maupun tidak berhubungan dengan pembelajaran".

Aktivitas belajar banyak jenisnya, misalnya menulis, berbicara, berpikir, diskusi, melakukan percobaan dan mengamati. Seperti yang dikemukakan oleh Paul D. Dierich (dalam Yamin 2013:85) bahwa jenis aktivitas belajar dikelompokkan menjadi delapan kelompok yaitu sebagai berikut: "1) kegiatan-kegiatan visual. 2) kegiatankegiatan lisan (oral). 3) kegiatankegiatan mendengarkan. 4) kegiatankegiatn menulis. 5) kegiatan-kegiatan menggambar. 6) kegiatan metrik. 7) kegiatan-kegiatan mental. 8) kegiatankegiatan emosional." Dari jenis-jenis aktivitas belajar tersebut, maka penulis akan menggunakan jenis-jenis aktivitas belajar tersebut sebagai pedoman untuk membuat lembar observasi aktivitas siswa pada proses belajar-mengajar.

Trianto (2013:53)

mengemukakan bahwa "model pembelajaran adalah kerangka konseptual yang melukiskan prosedur sistematik dalam mengorganisasikan pengalaman belajar untuk mencapai tujuan belajar tertentu dan berfungsi sebagai pedoman bagi perancang pembelajaran dan para guru dalam merancang dan melaksanakan pembelajaran."

Model project based learning merupakan model pembelajaran yang menuntut siswa untuk aktif dan kreatif dalam belajar. Sama halnya dengan yang dikemukan oleh Istarani (2012:156) yaitu : "belajar berbasis 
proyek (project based learning) adalah sebuah model atau pendekatan pembelajaran yang inovatif, yang menekankan belajar kontekstual melalui kegiatan-kegiatan yang kompleks. Fokus pembelajaran terletak pada konsep-konsep dan prinsipprinsip inti dari suatu disiplin studi, melibatkan pebelajar dalam investigasi pemecahan masalah dan kegiatan tugas-tugas bermakna lain, memberi kesempatan pebelajar bekerja secara otonom mengkonstruk pengetahuan mereka sendiri, mencapai puncaknya menghasilkan produk nyata".

$$
\text { Sani }
$$

mendefinisikan "project based learning sebagai sebuah pembelajaran dengan aktivitas jangka panjang yang melibatkan siswa dalam merancang, membuat, dan menampilkan produk untuk mengatasi permasalahan dunia nyata". Pembelajaran berbasis proyek akan membuat pengalaman belajar lebih menarik dan bermakna karena permasalah yang dikerjakan dalam proyek adalah permasalahan dunia nyata terutama bagi siswa SD. Sama halnya dengan pendapat Thomas (dalam Wena, 2014:144) yang menyatakan bahwa "Kerja proyek memuat tugas-tugas yang kompleks berdasarkan kepada pertanyaan dan permasalahan (problem) yang sangat menantang, dan menuntut siswa untuk merancang, memecahkan masalah, membuat keputusan, melakukan kegiatan investigasi, serta memberikan kesempatan kepada siswa untuk bekerja secara mandiri".

Menurut Thomas (dalam Wena 2014:145-146) prinsip-prinsip project based learning yaitu: "1) prinsip sentralistis (centrality) menegaskan bahwa proyek merupakan esensi kurikulum. Model ini merupakan pusat strategi pembelajaran, di mana siswa belajar konsep utama dari suatu pengetahuan melalui kerja proyek. 2) prinsip pertanyaan pendorong/penuntun (driving question) berarti bahwa kerja proyek berfokus pada "pertanyaan atau permasalahan" yang dapat mendorong siswa untuk berjuang memperoleh konsep atau prinsip utama suatu bidang tertentu. 3) prinsip investigasi konstruktif (constructive investigation) merupakan proses yang mengarah kepada pencapaian tujuan yang mengandung kegiatan inkuiri, pembangunan konsep, dan resolusi. 4) prinsip otonom (autonomy) dalam pembelajaran berbasis proyek dapat diartikan sebagai kemandirian siswa dalam melaksanakan proses pembelajaran, yaitu bebas menentukan pilihannya sendiri, bekerja dengan minimal supervisi, dam bertanggungjawab. 5) prinsip realistis (realism) berarti bahwa proyek merupakan sesuatu yang nyata, bukan seperti di sekolah".

Adapun langkah-langkah pembelajaran dalam project based learning menurut Sani (2014:181-182) yaitu: "1) penyajian permasalahan. Permasalahan diajukan dalam bentuk pertanyaan. 2) membuat perencanaan. 3) menyusun penjadwalan. Siswa harus membuat penjadwalan pelaksanaan proyek yang disepakati bersama guru. 4) memonitor pembuatan proyek. Pelaksanaan pekerjaan siswa harus dimonitori dan difasilitasi prosesnya, paling sedikit 
pada dua tahapan yang dilakukan siswa (checkpoint). 5) melakukan penilaian. Penilaian proyek merupakan kegiatan penilaian terhadap suatu tugas yang harus diselesaikan dalam periode/waktu tertentu. 6) evaluasi. Evaluasi dimaksudkan untuk memberikan kesempatan siswa dalam melakukan refleksi pembelajaran yang telah dilakukan baik secara individual maupun kelompok".

\section{METODE PENELITIAN}

Jenis penelitian ini adalah penelitian tindakan kelas (PTK) yang mengarah kepada penggunaan model pembelajaran project based learning dalam meingkatkan aktivitas belajar siswa pada materi pokok energi bunyi di kelas IV SD Negeri 101869 Desa Sena Kecamatan Batang Kuis Kabupaten Deli Serdang Tahun Ajaran 2014/2015. Subjek penelitian pada PTK ini adalah siswa kelas IV SD Negeri 101869 Desa Sena. Sedangkan objek penelitian ini adalah peningkatan aktivitas belajar siswa pada mata pelajaran IPA materi energi bunyi dengan menggunakan model project based learning.

Pengumpulan data dilakukan melalui observasi. Observasi ini dilakukan untuk mengamati aktivitas belajar siswa di kelas selama pembelajaran berlangsung dan untuk mengetahui sejauhmana keefektifan pelaksanaan pembelajaran dengan menggunakan model project based learning yang akan dilaksanakan. Desain penelitian ini menggunakan model siklus yang dikemukakan oleh Kemmis dan Mc. Targart daalam Suharsimi (2010 : 137). Dimana dalam tiap siklus terdapat empat komponen yaitu: perencanaan, Pelaksanaan, observasi dan refleksi.

Adapun skala tingkat keberhasilan aktivitas siswa secara klasikal digunakan untuk menyatakan penelitian ini berhasil adalah $\geq 65 \%$ siswa aktif.

Adapun langkah-langkah yang dilakukan pada siklus I dalam kegiatan perencanaan adalah sebagai berikut : 1) menyusun rencana pelaksanaan pembelajaran dengan menggunakan model project based learning. 2) mempersiapkan materi tentang energi bunyi, 3) mempersiapkan alat, bahan dan media pembelajaran yang akan digunakan dalam pembelajaran, 4) mempersiapkan lembar observasi kemampuan guru dan lembar observasi aktivitas belajar siswa.

Setelah perencanaan disusun dengan baik, maka dilakukan pelaksanaan tindakan dalam proses pembelajaran. Dalam satu siklus pelaksanaan tindakan dilakukan sebanyak 2 kali pertemuan.

Adapun kegiatan yang dilakukan dalam tahap pelaksanaan ini meliputi: 1) Peneliti bertindak sebagai guru dan melaksanakan proses pembelajaran sesuai dengan RPP yang telah disusun; 2) Guru menjelaskan secara umum tentang materi pembelajaran energi bunyi; 3) Guru membentuk beberapa kelompok. Setiap kelompok terdiri dari 5-6 orang siswa dengan kemampuan yang berbeda-beda; 3) Guru memberikan tugas berupa proyek kepada siswa; 4) Guru menjelaskan cara mengerjakan proyek; 5) Guru memberikan waktu kepada siswa untuk merencanakan dan 
menyusun penjadwalan pengerjaan proyek bersama teman sekelompoknya; 6) Siswa mempersiapkan bahan yang diperlukan untuk membuat proyek; dan 7) Siswa membuat proyek dengan dimonitori oleh guru. Masing-masing kelompok mempersentasikan proyek dan mendiskusikan tentang materi yang ditampilkan.

Observasi dilakukan terhadap pelaksanaan tindakan yang menggunakan lembar observasi yang telah disusun. Guru kelas bersama peneliti melakukan pengamatan dan mengisi lembar observasi untuk melihat aktivitas belajar siswa dan aktivitas guru terkait kesesuaian tindakan dengan rencana yang telah disusun.

Refleksi dalam penelitian tindakan kelas (PTK) ini mencakup analisis dan penilaian terhadap pelaksanaan tindakan dan observasi yang telah dilakukan. Refleksi ini dilakukan untuk mencari perbaikan-perbaikan tindakan selanjutnya. Sehingga dari data yang telah diperoleh dapat disimpulkan dari tindakan pada siklus I. Hasil refleksi ini yang akan mendasari perencanaan untuk siklus berikutnya bila tujuan yang diharapkan peneliti belum tercapai.

Langkah-langkah

dilakukan pada siklus II, pada kegiatan perencanaan adalah: 1) membuat rencana pelaksanaan pembelajaran (RPP), 2) mempersiapkan bahan ajar dengan pokok bahasan energi bunyi, dan 3) media pembelajaran. Pada tahap pelaksanaan dilakukan kegiatan pembelajaran sesuai dengan rencana pelaksanaan pembelajaran yang telah disusun dengan memperbaiki kelemahan pada siklus I. Observasi dilakukan selama proses pembelajaran berlangsung. Dengan mengamati aktivitas belajar siswa dan guru. Hasil observasi ditindaklanjuti dengan analisi untuk bahan refleksi. Refleksi ini dilakukan untuk mencari perbaikan - perbaikan tindakan selanjutnya. Sehingga dari data yang telah diperoleh dapat disimpulkan dari tindakan pada siklus II. Hasil refleksi ini yang akan mendasari perencanaan untuk siklus berikutnya bila tujuan yang diharapkan peneliti belum tercapai.

\section{HASIL DAN PEMBAHASAN}

Melalui model project based learning pada pokok bahasan energi bunyi terbukti dapat meningkatkan aktivitas belajar siswa secara optimal. Dapat dilihat dari nilai rata-rata klasikal siswa pada siklus I 67,82 dengan persentase $69,23 \%$ dan nilai rata-rata klasikal siswa pada siklus II mencapai 84,42 dengan persentase 96,15\%. Dan hasil observasi kemampuan guru pada siklus I 66,07\% dan pada siklus II mencapai $94,64 \%$. Berdasarkan keterangan di atas dapat disimpulkan bahwa aktivitas belajar siswa meningkat. Data peningkatan rata-rata kelas ditunjukkan pada Tabel 1.

Tabel 1. Peningkatan Rata-rata Kelas

\begin{tabular}{|c|c|c|}
\hline Siklus & Pertemuan & $\begin{array}{c}\text { Nilai } \\
\text { rata-rata }\end{array}$ \\
\hline I & I dan II & 67,82 \\
\hline II & I dan II & 84,42 \\
\hline
\end{tabular}


Berdasarkan Tabel 1 peningkatan nilai rata-rata klasikal aktivitas belajar siswa pada siklus I dan siklus II dapat juga ditunjukkan pada Gambar 1.

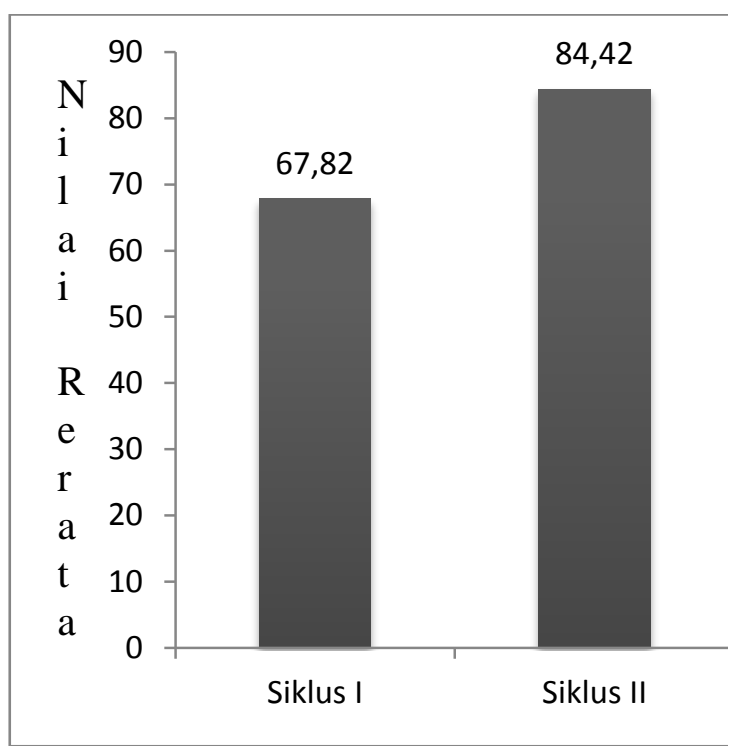

Gambar 1 Peningkatan Nilai Rata-rata

Nilai rata-rata kelas di siklus I adalalah 67,82 dan pada siklus II nilai rata-rata kelas adalah 84,42 . Sementara peningkatan jumlah siswa aktif dan persentase keberhasilan pada siklus I dan siklus II dirangkum pada Tabel 2.

Tabel 2 . Peningkatan Jumlah Siswa yang Aktif

\begin{tabular}{|c|c|c|c|}
\hline Siklus & Pertemuan & $\begin{array}{c}\text { Jumlah } \\
\text { siswa }\end{array}$ & Persentase \\
\hline I & I dan II & 18 & $69,23 \%$ \\
\hline II & I dan II & 25 & $96,15 \%$ \\
\hline
\end{tabular}

Data peningkatan jumlah siswa yang aktif dan persentase keberhasilan kelas pada siklus I dan siklus II dapatjuga ditunjukkan pada Gambar 2.

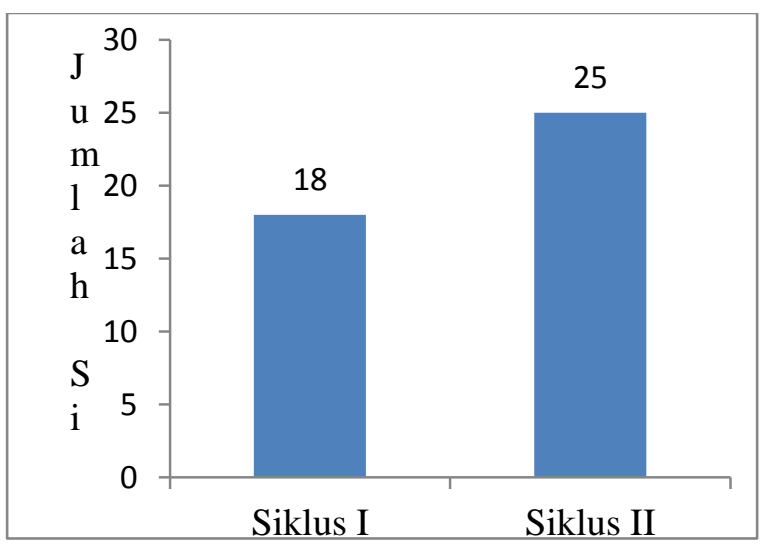

Gambar 2. Peningkatan jumlah siswa aktif

Terdapat 18 orang dengan persentase $69,23 \%$ siswa yang aktif di siklus I dan pada siklus II, siswa dengan presentase mencapai $96,15 \%$. Dari siklus I ke siklus II terjadi peningkatan aktivitas.

Berdasarkan data yang diperoleh tersebut ternyata hasil belajar siswa baik pada aspek pengetahuan dan aktivitas siswa dengan menggunakan model PjBL menunjukkan hasil yang baik. Hal ini sejalan dengan pernyataan Sani, (2014) bahwa dengan PjBL (1) siswa dilibatkan dalam permasalahan dunia nyata yang kompleks, (2) membutuhkan proses inkuiri, penelitian, keterampilan merencanakan, berpikir kritis dan keterampilan menyelesaikan masalah 
dalam upaya membuat proyek, (3) melibatkan siswa dalam belajar menerapkan pengetahuan dan keterampilan dengan konteks yang bervariasi ketika bekerja membuat proyek, (4) memberikan kesempatan pada siswa untuk belajar dan melatih kemampuan interpersonal ketika bekerja sama dalam kelompok, (5) memberikan kesempatan pada siswa untuk melatih keterampilan yang dibutuhkan untuk hidup dan bekerja dan (6) mencakup aktivitas refleksi yang mengarahkan siswa untuk berpikir kritis tentang pengalaman dan menghubungkan pengalaman tersebut pada standar belajar.

Model PjBL membantu siswa belajar dengan suasana pembelajaran yang bervariasi dan berbeda dari sebelumnya. Setiap siswa mempunyai gaya belajar yang berbeda, membangun pengetahuan dan pengalamannya dengan cara yang berbeda. PjBL adalah model untuk kegiatan kelas yang berbeda jauh dari kegiatan kelas biasa, terisolasi, pelajaran berpusat pada guru. Kegiatan $\mathrm{PjBL}$ interdisipliner dan berpusat pada siswa dan terintegrasi dengan isu-isu dan praktek pada dunia nyata. Dengan PjBL, siswa mengeksplorasi, membuat penilaian, menafsirkan dan mensitesis informasi dalam cara yang berarti (Harun, 2006).

\section{KESIMPULAN DAN SARAN Kesimpulan}

Berdasarkan hasil pembahasan penelitian tindakan kelas yang dilakukan dengan menerapkan model project based learning untuk meningkatkan aktivitas belajar siswa pada pokok bahasan energi bunyi di kelas IV SD Negeri No. 101869 Desa Sena dapat ditarik kesimpulan:

1. Dengan menggunakan model project based learning dapat meningkatkan aktivitas belajar siswa pada pokok bahasan energi bunyi dan hal ini terlihat dari peningkatan aktivitas belajar siswa dalam setiap pertemuan.

2. Terdapat peningkatan aktivitas siswa secara individu. Dari 26 siswa, terdapat 26 siswa yang mengalami peningkatan selama penelitian.

3. Terdapat peningkatan nilai ratarata pada pada siklus I dan siklus II. Pada siklus I nilai rata-rata siswa adalah 67,82 dan pada siklus II adalah 84,42.

4. Pada siklus I jumlah siswa yang aktif ada 18 orang siswa dengan persentase $69,23 \%$ dan siswa yang belum aktif ada 8 orang siswa dengan persentase $30,76 \%$. Pada siklus II jumlah siswa aktif 25 orang dengan persentase mencapai $96,15 \%$ dan 1 orang tidak aktif dengan persentase $3,85 \%$.

\section{Saran}

1. Siswa sebaiknya terlibat aktif dalam proses pembelajaran. Karena aktivitas belajar akan meningkatkan keberhasilan belajar.

2. Mengajar dengan menggunakan model project based learning pada mata pelajaran IPA dapat meningkatkan aktivitas belajar. Karena itu guru perlu 
menggunakan model project based learning atau pun model - model lainnya yang dapat meningkatkan aktivitas belajar siswa.

3. Sebagai pengajar, guru disarankan untuk lebih aktif lagi melakukan penelitian tindakan kelas karena penelitian yang dilakukan sangat berguna siswa dan menambah keterampilan guru.

4. Saran bagi peneliti, hendaknya terus mengkaji berbagai model pembelajaran agar dapat menjadi referensi ketika mengajar dimasa mendatang.

\section{DAFTAR PUSTAKA}

Daryanto. 2010. Belajar dan Mengajar. Bandung : Yrama Widya.

Harun, bin Y., (2006), Project-Based Learning Handbook, Educational Technology Division: Kuala Lumpur

Istarani. 2012. 58 Model Pembelajaran Inovatif. Medan : Media Persada.

Sani, Ridwan Abdullah. 2014. Pembelajaran Saintifik untuk Implimentasi Kurikulum 2013. Jakarta : Bumi Aksara.
Sardiman. 2011. Interaksi \& Motivasi Belajar Mengajar. Jakarta : Rajagrafindo Persada.

Suharsimi Arikunto. 2010. Prosedur Penelitian Suatu Pendekatan Praktik. Jakarta: Rineka Cipta.

.Trianto. 2011. Mendesain Model Pembelajaran InovatifProgresif: Konsep. Landasan, dan Implementasinya pada Kurikulum Tingkat Satuan Pendidikan (KTSP) . Jakarta: Kencana.

.2013. Model Pembelajaran Terpadu: Konsep, Strategi, dan Implementasinya dalam Kurikulum Tingkat Satuan Pendidikan (KTSP). Jakarta : Bumi Aksara.

Wena, Made. 2014. Strategi Pembelajaran Inovatif Kontemporer. Jakarta : Bumi Aksara.

Yamin, Martinis. 2013. Kiat Membelajarkan Siswa. Jakarta : GP Press Group. 